\title{
Assessment of Innovative Skill Development in Weekend Challenges
}

\section{Ms. Magdalini Z Lagoudas, Texas A\&M University}

Magda Lagoudas, Executive Director for Industry and Nonprofit Partnerships, Dwight Look College of Engineering, Texas A\&M University. Mrs. Lagoudas holds a BS and MS in Mechanical Engineering. She worked for the State of New York and industry before joining Texas A\&M University in 1992. Since then, she developed and taught courses in the Departments of Mechanical Engineering and Engineering Technology. In 2001, she joined the Spacecraft Technology Center as an Assistant Director where she was responsible for the structural and thermal analysis of payloads. She served as Director of the Space Engineering Institute and in 2010 she accepted a position with the Academic Affairs office of the Dwight Look College of Engineering where she oversaw outreach, recruiting, retention and enrichment programs for the college. Since 2013, she serves as the Executive Director for Industry and Nonprofit Partnerships with responsibilities to increase opportunities for undergraduates engineering students to engage in experiential learning multidisciplinary team projects. These include promoting capstone design projects sponsored by industry, developing and teaching the Engineering Projects in Community Service course, and developing curricular and co-curricular programs at the Engineering Innovation Center which promote innovation and entrepreneurship among engineering students and in collaborations with other colleges on campus and partnering with other institutions across the country

\section{Mr. Rodney Boehm, Engineering Academic and Student Affairs}

Rodney Boehm has joined the Engineering Academic and Student Affairs (EASA) team as an Industry Mentor with very broad experiences, including the creation of a telecommunications standard for the fiber optics industry that is still in use internationally over 25 years later, a wide variety of business experiences in an international company, and start up experience that have helped him hone his ability to quickly determine a direction and execute to it.

He is also formerly the Chief Operating Officer for GroundFORCE, a company that specializes in a unique patented construction technology. His extensive experience in running sales, marketing, manufacturing, and large multi-national organizations was applied to introducing this new technology to the construction industry.

Formerly he was a Senior Vice President of Fujitsu Network Communications, headquartered in Richardson, Texas. With over 30 years of experience in telecommunications, Rodney was responsible for developing partnerships with leading network technology providers and driving marketing efforts for optical, access and data products developed by Fujitsu. Along with Yau Chow Ching, Rodney conceived (and wrote the standards for), the SONET (Synchronous Optical Network) architecture, which served as the base for today's North American telephone network. Rodney was Chairman of the T1X1 Technical SubCommittee (the organization responsible for SONET standardization) from 1990 through 1994. He has been active in SONET's National and International Standardization since 1985. In addition, Rodney has published numerous papers and presentations on SONET.

Rodney began his career with Fujitsu Network Communications in 1989 as the Director of Strategic Planning. He also held the positions of Director of Transport Product Planning, Vice President of Business Management, Senior Vice President of Sales Management, Senior Vice President of Manufacturing, and Senior Vice President of Business Development. Before joining Fujitsu, Rodney worked for Bell Laboratories, Bellcore (now Telcordia), and Rockwell International. He earned both his bachelor's and master's degrees in electrical engineering at Texas A\&M University.

\section{Mr. James L Wilson, Texas A\&M University - College of Engineering}

8 years USAF. 24 years experience in IT, Laboratory Management, Facilities Management and System Design. Received Bachelors from LeTourneau University in Education Technology. Masters from Texas A\&M Commerce in Engineering Technology. Currently the Facility Manager of the Texas A\&M Engineering Innovation Center. 


\section{Assessment of Student Outcomes in a 48-Hour Intensive Innovation Experience}

\section{Introduction}

Recent reports $(1,2)$ have highlighted the need to promote development of innovative skills and entrepreneurial mindsets among undergraduate engineering students. This paper will focus on a new extracurricular 48-hour weekend Intensive Innovation Experience (IIE) designed to provide teams of engineering undergraduates opportunities to pursue rapid development of hardware prototypes for needs identified by industry and non-profit organizations. Over the 48-hours, program participants have access to the maker facility, professional staff, and industry and graduate student mentors. At the end of the event, student teams present their designs and compete for awards. After the conclusion of the event, student teams are encouraged to pursue their innovative solutions to further maturation. This paper will first provide an overview of how the program that was launched in Summer 2014, was developed and implemented. It has been offered three times since then. Next, the authors will present data on achievement of student outcomes in five areas: 1) understanding the design process, 2) problem solving, 3) effective communications, 4) team work, and 5) time management. Finally, the paper will present demographics and post-graduation plans of program participants. For program dissemination, the authors will present detailed program information at the poster session hosted at the same conference.

\section{Background}

In 2011, the National Advisory Council on Innovation and Entrepreneurship (NACIE) members submitted a letter entitled "Recommendation to Facilitate University-Based Technology Commercialization" (1) to Secretary of Commerce Locke. The letter, signed by 146 of America's leading institutions, included in the recommendations the need to develop student programs to provide new opportunities for experiential learning and promote student innovation and entrepreneurship. In response to the above letter, the US Department of Commerce conducted a series of interviews with institutions across the nation in an effort to understand how universities are nurturing and promoting innovation/entrepreneurship and published the "The Innovative and Entrepreneurial University; Higher Education, Innovation \& Entrepreneurship in Focus" (2). While there is significant research on innovation and entrepreneurship within the formal curriculum $(3,4)$ there is less focus on extracurricular programs. Authors believe informal programs offer a great opportunity to engage engineering students in activities promoting innovation and entrepreneurship as it has been shown by the impact of Innovation Challenges on the development of innovative skills (5). Per C. Amelink et al. (5), innovative thinking skills include: a) critical thinking and effective generation of new ideas, b) application and integration of science/engineering content knowledge, c) ability to organize new information/ideas/products articulately, d) ability to communicate ideas to peers and others, effective use of technology/tool selection in design process, e) complex thinking process that transforms a creative idea into useful services/products, 
potential for prototyping/commercialization. The program discussed here has been developed to promote innovation with focus on the following learning outcomes: Understanding of Design (a thru e), Problem Solving (a thru e), Teamwork (d), Effective Communication (d), and Time Management (d). Each of the desired learning outcomes are connected to one or more of the innovative thinking skills identified by (5). This paper describes an overview of the development and implementation of a unique informal program and the assessment data from student surveys. The program brings together students from across several engineering majors and classifications to work intensely for 48 hours to develop and build rapid prototypes, solving problems (described by Need statements) sponsored by industry and nonprofit organizations.

\section{Program Development and Implementation}

The program is an intense creative and innovative weekend event, which challenges students to solve real world industry and agency problems by using the varied skills of each team member. At times, this process can be chaotic, messy, and tense but incredibly rewarding for the students and sponsors. The program is offered every semester and each time the theme of the program is different thus targeting students with different interests. Because the program is so intense, it requires well-structured approaches in four key areas: preparation, delivery, facility, and follow-up.

\section{Preparation}

There are three key threads throughout the process of preparing for the program. The first is establishing the overall theme. The theme is the single item that will rally sponsors, mentors, and students. Past themes include wearable technologies, medical devices, and solutions for first responders. These were considered because of the wealth of opportunities they provide for sponsors to identify problems and also because of student interest. The second thread is gathering need statements, Mentors, and planning for anticipated needs. Need statements define the problem that a sponsoring organization wants solved. Successful need statements are open design problems where students will have a chance to make significant progress towards a solution over the weekend. Because there is little time to obtain additional material during the weekend, it is critical that faculty/staff gain a basic understanding of potential solutions to these needs and gather supplies and support that students might need. Anticipating supply needs beforehand enhances student's ability to create. While certain technologies are important to have on hand, many times the messy creative design experience depends on tape, cardboard, glue, rubber bands, and sticky notes. It is also important to have faculty/staff on hand that are resources for key technologies or construction platforms providing support and answering questions. Finally, the third thread is people. This starts with Sponsors who help fund the event, Mentors who support Need statements, Faculty/Staff who provide the background resources, and Students who brainstorm concept ideas, develop prototypes and present the final solution to the sponsoring organization. Student participants are selected through an application process where applicants list their academic skills, 
related experiences, and interest in the theme. The applicant selection process also considers freshmen and sophomores who might not have significant technical skills but demonstrate strong interest in the theme.

\section{Delivery}

The program starts with student participants meeting the industry sponsors to learn more about the proposed need statements. Following that, project teams (5-6 students per team) are formed based on student project preferences. Each team meets their industry mentor to discuss the details of the project scope and design requirements to design an acceptable solution. The rest of the weekend is spent in developing and testing prototype solutions, in collaboration with the industry mentors. Table 1 provides a program overview.

\section{Table 1. Program Overview}

\begin{tabular}{|l|l|l|}
\hline \multicolumn{1}{|c|}{ Activity } & \multicolumn{1}{|c|}{ Description } & \multicolumn{1}{c|}{ Purpose } \\
\hline Overview & $\begin{array}{l}\text { Briefly explain the process, resources } \\
\text { available (physical and people), } \\
\text { facility use, and schedule }\end{array}$ & $\begin{array}{l}\text { Introduce students to full capabilities of the } \\
\text { facilities as quickly as possible to maximize } \\
\text { results }\end{array}$ \\
\hline Motivation & $\begin{array}{l}\text { Inspire with videos, music, ice } \\
\text { breakers, or innovative people }\end{array}$ & $\begin{array}{l}\text { Foster an environment to break down } \\
\text { barriers, try new concepts, push beyond } \\
\text { Needs, challenge status quo, set the culture }\end{array}$ \\
\hline $\begin{array}{l}\text { Team } \\
\text { Formation }\end{array}$ & $\begin{array}{l}\text { Students select Needs to work on and } \\
\text { self-select team members }\end{array}$ & $\begin{array}{l}\text { Insures students work on something that } \\
\text { interests them with people they want to } \\
\text { spend the weekend with }\end{array}$ \\
\hline $\begin{array}{l}\text { Prototype } \\
\text { Development }\end{array}$ & $\begin{array}{l}\text { Develop conceptual designs, identify } \\
\text { baseline design, develop prototype, } \\
\text { test and update design, if needed. }\end{array}$ & $\begin{array}{l}\text { Provides students an opportunity to apply } \\
\text { science and engineering skills in solving a } \\
\text { real world problem and also practice the } \\
\text { engineering design process }\end{array}$ \\
\hline Checkpoints & $\begin{array}{l}\text { Short checkpoint reviews with } \\
\text { faculty/staff to ensure progress, solve } \\
\text { roadblocks, suggest additional } \\
\text { work/considerations }\end{array}$ & $\begin{array}{l}\text { Provides accountability and identifies teams } \\
\text { who are fixated and need to be pushed } \\
\text { further }\end{array}$ \\
\hline Presentation & $\begin{array}{l}\text { Teams present design solutions / } \\
\text { products to judges }\end{array}$ & Encourages effective communication \\
\hline
\end{tabular}

\section{Project Examples}

Each weekend experience is designed with an overall theme. Project sponsors include industry, nonprofits organizations such as Red Cross and local hospitals, and government agencies such as NASA, Sandia Labs, and the United States Air Force. Below is a short description of three projects of the program:

- Design a multi-purpose tool which combines the functions of several tools into one tool to be used by first responders dealing with hazardous materials.

- Design a low-cost fire alert network system which can be installed in heavily "populated areas in developing counties to alert occupants in case of fire anywhere in the vicinity.

- Design a system which will monitor at risk neonates and collect vital health information without attaching anything to the infant. 


\section{Student Participation}

The inaugural program was offered in 2014 summer with forty-three student participants while the fall 2014 program engaged sixty-three students. As it is shown in Figures 1 thru 4, the program attracts students from freshman to graduate students and also participants represent many engineering majors and with a small fraction of participants being from another college.

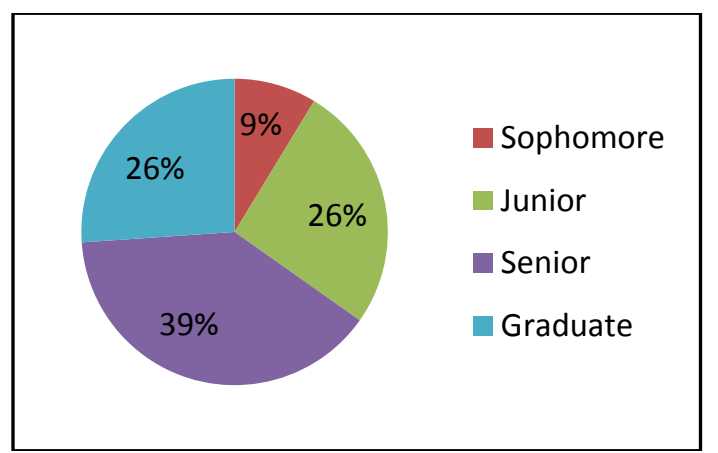

Figure 1. Participant Classification (summer 2014)

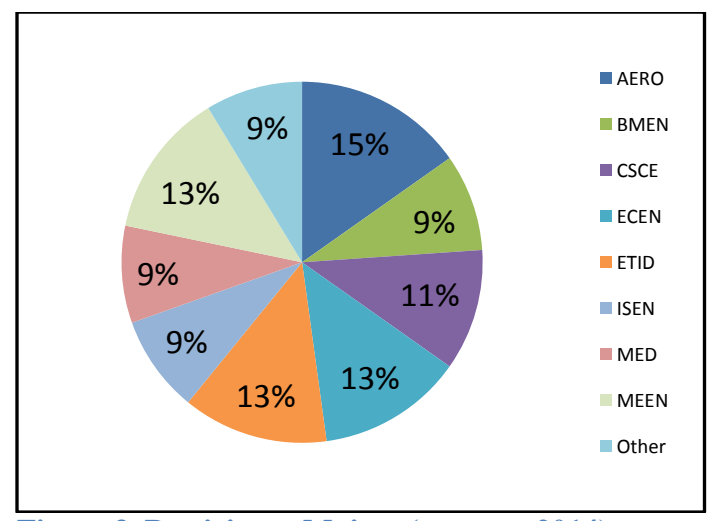

Figure 3. Participant Majors (summer 2014)

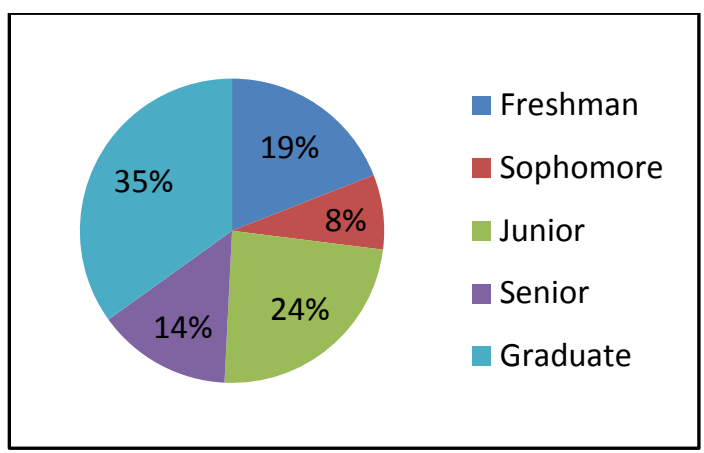

Figure 2. Participant Classification (fall 2014)

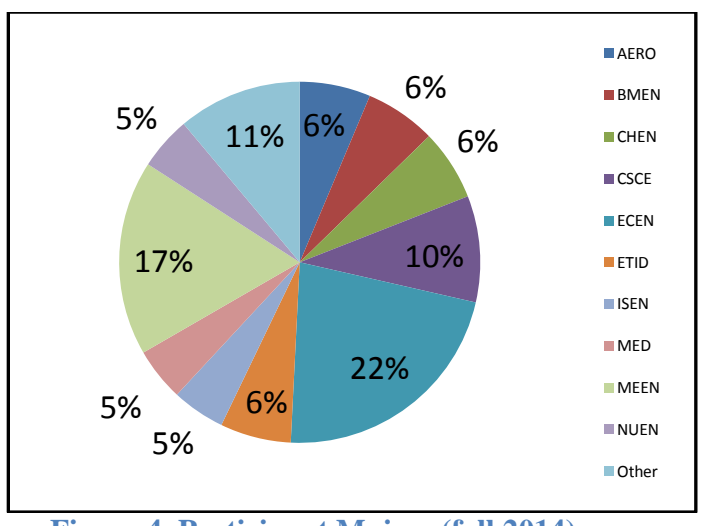

Figure 4. Participant Majors (fall 2014)

\section{Facility}

A critical component of any successful program is the space that supports and facilitates implementation. Many have called this a "Maker Space" which describes its function - enable students to "Make/Build" their ideas. The institution has established a 20,000 square feet facility dedicated solely to engineering undergraduates. The facility was developed to provide a multi-functional workspace for undergraduate engineering students. Primary users fall into three categories, senior capstone design teams, various multidisciplinary and vertically integrated teams, and student design competitions. Other students have access to the facility by participating in a variety of programs offered at the facility to promote innovation. These include the 48-hour program described in this paper, training sessions in more than twenty topics, and other special events. The facility provides collaborative 
workspace, project storage space, specialty workstations, fabrication facilities, access to electronic components, conference rooms, digital media room, and professional staff. The specialty workstations include: weights and measurements, soldering, industrial sewing, hand tools, electronic measuring, and wet lab. Students have access to an extensive list of components, which include electronic sensors, programmable controllers, and nuts and bolts. The facility includes a 7,000 square feet fabrication center which consists of a machine shop (lathes, mills, sanding, grinding, and cutting), prototyping center (Stratasys and other type 3D printers, laser cutter, and fabrication for printed circuit boards), woodshop, welding lab and paint rooms. In addition, the facility is supported by two full time professional staff and several student workers.

\section{Follow-Up}

Based on student feedback, the program offers a follow-up event for students interested in pursuing their project after the program concludes. To facilitate this, interested teams are invited to attend an event where they are presented with campuswide resources available to them. These include mentors associated with the institution who can support the teams as they continue developing their idea, resources for intellectual property, and access to a university student incubator.

\section{Achievement of Student Outcomes}

The program participants were asked to provide feedback in an online survey. The survey, Appendix A, includes questions from several previous studies of student assessment outcomes $(6,7)$ and also new questions designed to capture student input for areas unique to the program. Overall, $67 \%$ of the summer program participants and $68 \%$ of the fall program participants participated in the online survey.

Understanding the Design Process: Participants were asked to rate their growth in a five-level Likert-type scale (strongly agree / agree/ not sure/ disagree/ strongly disagree) in their ability to:

- identify critical needs /requirements in an open ended problem (Q1)

- develop and evaluate conceptual designs and select best fits (Q2)

- integrate hardware and software for prototype development (Q3)

- utilize modern rapid prototyping tools for prototype demonstration (Q4)

- apply mathematics, science, and engineering knowledge to evaluate prototype performance (Q5)

- $\quad$ understand the process of design in engineering (Q7)

As shown in Figure 5, more than $90 \%$ of participants agree or strongly agree that as a result of their involvement in the program they have improved their ability to identify critical needs/requirements (Q1), develop and evaluate conceptual design (Q2), integrate hardware and software $(\mathrm{Q} 3)$ and understand the process of design $(\mathrm{Q} 7)$. 


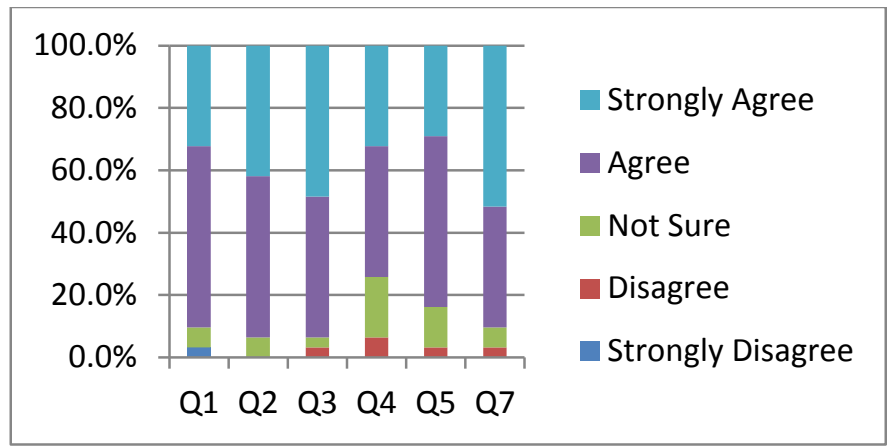

Figure 5. Design Process

Problem Solving: Participants were asked to rate their growth (in a similar five-level Likert-type scale) in their ability to:

- identify what information is needed to solve a problem (Q8)

- apply an abstract concept or idea to a real problem or situation (Q9)

- divide problems into manageable components (Q10)

- develop several methods that might be used to solve a problem (Q11)

- use established criteria to evaluate and prioritize solutions (Q12)

As shown in Figure 6, more than $90 \%$ of participants strongly agree or agree that they have improved their ability in problem solving skills associated with questions Q8, Q9, Q10, Q12.

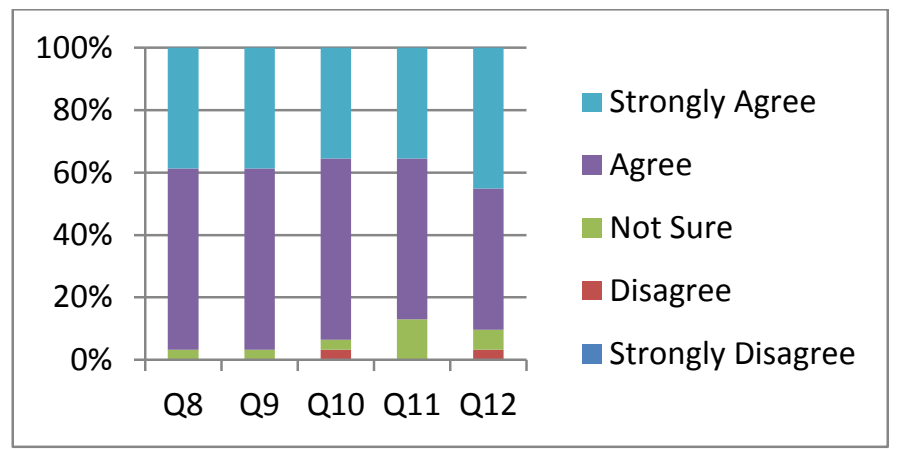

Figure 6. Problem Solving

Effective Communication: Participants were asked to rate their growth (in a five-level Likert-type scale) in their ability to:

- clearly describe a problem orally (Q13)

- clearly describe a problem in writing (Q14)

- $\quad$ showcase their skills to others (Q15)

More than $80 \%$ of participants strongly agree or agree (figure 7) that they have improved their ability for oral presentations (Q13) and showcasing their skills to others (15) while there is less improvement in describing a problem in writing since the program did not include many opportunities for participants to develop written reports. 


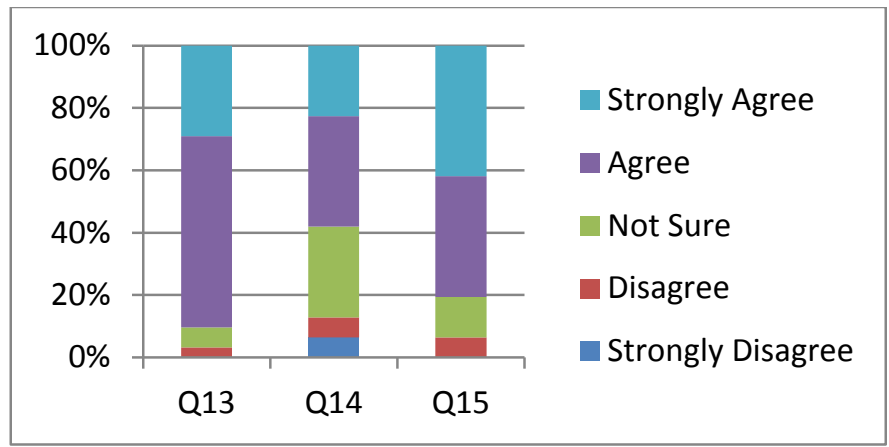

Figure 7. Effective Communication

Teamwork: Participants were asked to rate their growth (in a five-level Likert-type scale) in their ability to:

- develop ways to resolve conflict and reach agreement in a group (Q16)

- be aware of feelings of other members of the group (Q17)

- listen to the ideas of others with an open mind (Q18)

- work on collaborative projects as a team member (Q19)

- ask probing questions that clarify facts, concepts, or relationships (Q20)

- after evaluating the alternatives generated, develop a new alternative that combines the best qualities and avoids the disadvantages of the previous alternatives $(\mathrm{Q} 21)$

- evaluate arguments and evidence so that strengths and weaknesses of competing alternatives can be judged (Q22)

- be patient and tolerate the ideas or solutions proposed by others (Q23)

- understand that a problem may have multiple solutions (Q24)

- use discussion strategies to analyze and solve a problem (Q25)

- recognize contradictions or inconsistencies in ideas, data, images (Q26)

- recognize flaws in my own thinking (Q27)

- identify the constraints on the practical application of an idea (Q28)

More than $77 \%$ of participants strongly agree or agree (Figure 8 ) that they have improved their ability in all areas of teamwork questions.

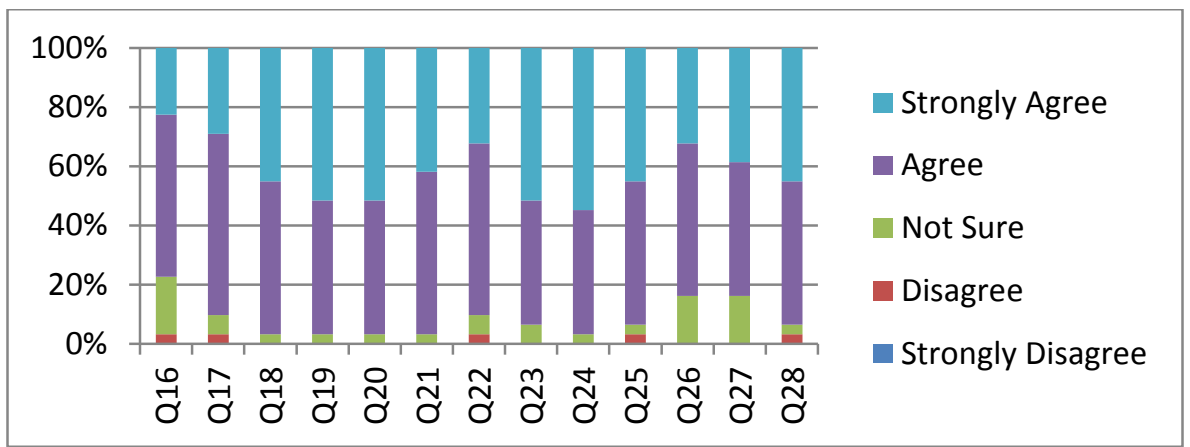

Figure 8. Teamwork

Time Management: Participants were asked to rate their growth (in a five-level Likert-type scale) in their ability to: 
- estimate required time for each task (Q29)

- prioritize tasks in the order of their importance and relevance $(\mathrm{Q} 30)$

- adhere to a timeline $(\mathrm{Q} 31)$

The intensity of the program encourages students to practice good time management skills and as shown in Figure 9 more than $80 \%$ of participants strongly agree or agree that they have improved their time management skills (questions Q29-Q31).

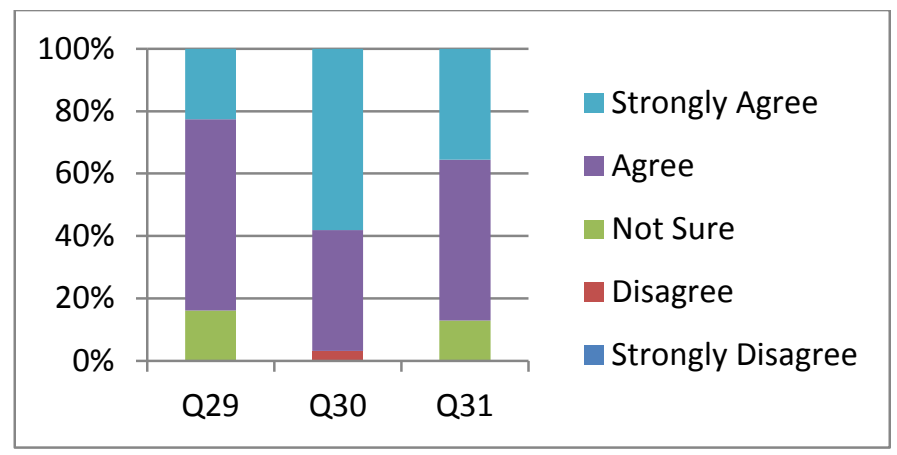

Figure 9. Time Management

Reasons for Participating: Furthermore, authors are interested to investigate the types of students attracted to this program since this type of data will assist efforts to further improve the program. Participants were asked for their reason for participating in the weekend experience:

- have a general interest in program theme (Q32)

- have a general interest in innovation (Q33)

- have a general interest in building prototypes (Q34)

- broaden your career prospects and choices (Q35)

- want to examine my own qualifications (Q36)

- want to become an entrepreneur (Q37)

- have an idea for a business or product (Q38)

As shown in Figure 10, more than 97\% of participants strongly agree / agree that they participated in the program because they have a general interest on innovation while $87 \%$ of participants stated also that the reason for participating was to broaden their career prospects (strongly agree/agree).

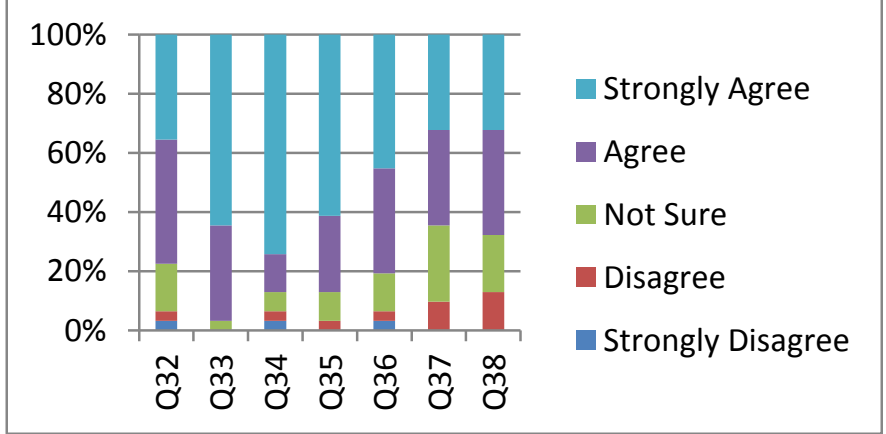

Figure 10. Reason for Participation 
Post-graduation Plans: Figure 11 shows participant response when they were asked about Participants were about their post-graduation plans:

- $\quad$ work for a large-sized corporation (Q39)

- $\quad$ work for a medium-sized business (Q40)

- work for a small-sized business (Q41)

- work for a non-profit organization (Q42)

- work for the government (Q43)

- $\quad$ pursue graduate studies $(\mathrm{Q} 44)$

- $\quad$ start own business (Q45)

More than $61 \%$ strongly agree / agree that their post-graduation plans include starting their own business while 52\% strongly agree / agree that they will pursue graduate studies (participants provided input for multiple post-graduation plans).

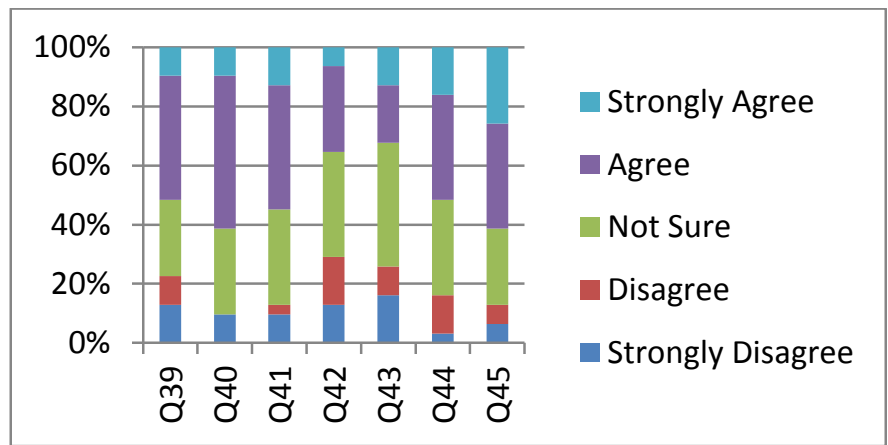

Figure 11. Post-graduation Plans

Value to Professional Career: Participants were also asked (Q46): what were the most valuable aspects of your experience with the program for your professional career? Below are some of participant responses related to the above learning outcome categories:

- Understanding the Design Process - One student wrote: "The most valuable aspect of this event was learning how to apply the engineering method to a real life issue with completely random strangers and producing a prototype in a minute amount of time. Then finally cap it all off, being able to communicate and present this idea and prototype to an audience" while another student wrote: "I learned how to navigate the design process under very limited time constraints".

- Teamwork - One student wrote: "Learning to grow up and accept that my idea wasn't the best while keeping my full effort in the project" while another student wrote: "Being able to collaborate with others from different fields of study than myself allowed me to grow and be able to express what I want in a way that makes sense to someone other than myself".

- Effective Communication - One student wrote: "Usually I am not the one to get up in front of people to give a presentation but the program helped me step out of my comfort zone. After presenting, I feel more confident with presenting in front of people. I am also more comfortable opening my ideas up 
to the group, because some of my ideas were actually implemented into our design" while another student wrote: "Ability to do oral presentations and sell an idea".

- Problem Solving - One student wrote: "Gaining experience developing ideas to solve complex problems that can positively affect the lives of others" while another student wrote: "Being able to apply what I learned in the classroom to a real life scenario with all modern technology and support".

- Time Management - One student wrote: "Managing the project and keeping everyone on task and focused on the actual problem, not the variety of solutions available" while another student wrote: "The ability to look at the need and organize time and resources to get the task accomplished".

- Other - One student wrote: "The experience afforded me the opportunity to network and establish my own confidence in myself by taking on a challenge that was widely outside my comfort zone" while another student wrote: "I had a blast, and what made all of the time and work worth it, the hours upon end of drafting it and finally assembling it, was walking out at the end of the day with the $1^{\text {st }}$ place title. With that said, everyone walked out of ... with a smile on their face, because I know from first-hand experience that everyone had a great time".

\section{Discussion}

Student survey data demonstrate the value students see in participating in this informal weekend Intensive Innovation Experience program with industry sponsored needs, mentors, and access to resources for rapid prototyping development and testing. The program has been very successful with students and the authors are considering to offer a longer version of the program between fall/spring or spring/summer semesters to accommodate student needs. The authors would like to express their appreciation to all the industry and nonprofit sponsors and mentors who greatly contributed to the success of the program.

Authors have received IRB approval for this study. 


\section{Appendix A - Survey Questions}

\begin{tabular}{|c|c|c|}
\hline & Skills / Knowledge & Question \\
\hline \multicolumn{3}{|c|}{$\begin{array}{l}\text { Please rate your growth in the following. } \\
\text { As a result of my involvement in the program, I improved my ability to: }\end{array}$} \\
\hline Q1 & Design Process & Identify critical needs /requirements in an open ended problem \\
\hline Q2 & Design Process & Develop and evaluate conceptual designs and select best fits \\
\hline Q3 & Design Process & Integrate hardware and software for prototype development \\
\hline Q4 & Design Process & Utilize modern rapid prototyping tools for prototype demonstration \\
\hline Q5 & Design Process & $\begin{array}{l}\text { Apply mathematics, science, and engineering knowledge to evaluate prototype } \\
\text { performance }\end{array}$ \\
\hline Q6 & Societal Impact & Understand what engineering can contribute to society \\
\hline Q7 & $\begin{array}{l}\text { Design } \\
\text { Process }\end{array}$ & Understand the process of design in engineering \\
\hline \multicolumn{3}{|c|}{$\begin{array}{l}\text { Please rate your growth in the following. } \\
\text { As a result of my involvement in the program, I improved my ability to: }\end{array}$} \\
\hline Q8 & Problem Solving & Identify what information is needed to solve a problem \\
\hline Q9 & Problem Solving & Apply an abstract concept or idea to a real problem or situation \\
\hline Q10 & Problem Solving & Divide problems into manageable components \\
\hline Q11 & Problem Solving & Develop several methods that might be used to solve a problem \\
\hline Q12 & Problem Solving & Use established criteria to evaluate and prioritize solutions \\
\hline \multicolumn{3}{|c|}{$\begin{array}{l}\text { Please rate your growth in the following. } \\
\text { As a result of my involvement in the program, I improved my ability to: }\end{array}$} \\
\hline Q13 & Communication & Clearly describe a problem orally \\
\hline Q14 & Communication & Clearly describe a problem in writing \\
\hline Q15 & Communication & Showcase my skills to others \\
\hline \multicolumn{3}{|c|}{$\begin{array}{l}\text { Please rate your growth in the following. } \\
\text { As a result of my involvement in the program, I improved my ability to: }\end{array}$} \\
\hline Q16 & Teamwork & Develop ways to resolve conflict and reach agreement in a group \\
\hline Q17 & Teamwork & Be aware of feelings of other members of the group \\
\hline Q18 & Teamwork & Listen to the ideas of others with an open mind \\
\hline Q19 & Teamwork & Work on collaborative projects as a team member \\
\hline Q20 & Teamwork & Ask probing questions that clarify facts, concepts, or relationships \\
\hline Q21 & Teamwork & $\begin{array}{l}\text { After evaluating the alternatives generated, develop a new alternative that } \\
\text { combines the best qualities and avoids the disadvantages of the previous } \\
\text { alternatives }\end{array}$ \\
\hline Q22 & Teamwork & $\begin{array}{l}\text { Evaluate arguments and evidence so that strengths and weaknesses of competing } \\
\text { alternatives can be judged }\end{array}$ \\
\hline Q23 & Teamwork & Be patient and tolerate the ideas or solutions proposed by others \\
\hline \multicolumn{3}{|c|}{$\begin{array}{l}\text { Please rate your growth in the following. } \\
\text { As a result of my involvement in the program, I improved my ability to: }\end{array}$} \\
\hline Q24 & Teamwork & Understand that a problem may have multiple solutions \\
\hline Q25 & Teamwork & Use discussion strategies to analyze and solve a problem \\
\hline Q26 & Teamwork & Recognize contradictions or inconsistencies in ideas, data, images \\
\hline
\end{tabular}




\begin{tabular}{|c|c|c|}
\hline Q27 & Teamwork & Recognize flaws in my own thinking \\
\hline Q28 & Teamwork & Identify the constraints on the practical application of an idea \\
\hline \multicolumn{3}{|c|}{$\begin{array}{l}\text { Please rate your growth in the following. } \\
\text { As a result of my involvement in the program, I improved my ability to: }\end{array}$} \\
\hline Q29 & Time Management & Estimate required time for each track \\
\hline Q30 & Time Management & Prioritize tasks in the order of their importance and relevance \\
\hline Q31 & Time Management & Adhere to a timeline \\
\hline \multicolumn{3}{|c|}{ Please indicate your reasons for participating in Aggies Invent: } \\
\hline Q32 & $\begin{array}{l}\text { Reasons for } \\
\text { Participating }\end{array}$ & Have a general interest in program theme \\
\hline Q33 & $\begin{array}{l}\text { Reasons for } \\
\text { Participating }\end{array}$ & Have a general interest in innovation \\
\hline Q34 & $\begin{array}{l}\text { Reasons for } \\
\text { Participating }\end{array}$ & Have a general interest in building prototypes \\
\hline Q35 & $\begin{array}{l}\text { Reasons for } \\
\text { Participating }\end{array}$ & Broaden my career prospects and choices \\
\hline Q36 & $\begin{array}{l}\text { Reasons for } \\
\text { Participating }\end{array}$ & Want to examine my own qualifications \\
\hline Q37 & $\begin{array}{l}\text { Reasons for } \\
\text { Participating }\end{array}$ & Want to become an entrepreneur \\
\hline Q38 & $\begin{array}{l}\text { Reasons for } \\
\text { Participating }\end{array}$ & Have an idea for a business or product \\
\hline \multicolumn{3}{|c|}{ Please indicate your plans post-graduation: } \\
\hline Q39 & $\begin{array}{l}\text { Post-Graduation } \\
\text { Plans }\end{array}$ & Work for large-sized corporation \\
\hline Q40 & $\begin{array}{l}\text { Post-Graduation } \\
\text { Plans }\end{array}$ & Work for medium-sized business \\
\hline Q41 & $\begin{array}{l}\text { Post-Graduation } \\
\text { Plans }\end{array}$ & Work for a small sized business \\
\hline Q42 & $\begin{array}{l}\text { Post-Graduation } \\
\text { Plans }\end{array}$ & Work for a non-profit organization \\
\hline Q43 & $\begin{array}{l}\text { Post-Graduation } \\
\text { Plans }\end{array}$ & Work for government \\
\hline Q44 & $\begin{array}{l}\text { Post-Graduation } \\
\text { Plans }\end{array}$ & Pursue graduate studies \\
\hline Q45 & $\begin{array}{l}\text { Post-Graduation } \\
\text { Plans }\end{array}$ & Start own business \\
\hline \multicolumn{3}{|c|}{ Overall Questions: Please help us understand your experience at Aggies Invent in depth, } \\
\hline Q46 & Other & $\begin{array}{l}\text { What were the most valuable aspects of your experience with the program for } \\
\text { your professional career? }\end{array}$ \\
\hline Q47 & Other & What was the most valuable asset Facility asset for your design project? \\
\hline Q48 & Other & What were the benefits of your interactions with industry / nonprofit sponsors? \\
\hline Q49 & Other & Are you planning to pursue your project after today? \\
\hline Q50 & Other & Are you planning to keep in touch with any of the industry sponsors in the future? \\
\hline Q51 & Other & Are you planning to pursue your project after today? \\
\hline Q52 & Other & Would you be interested to have access to the Facility and for which reason? \\
\hline Q53 & Other & $\begin{array}{l}\text { What Improvements would you make to the program to make it more valuable to } \\
\text { undergraduate engineering students? }\end{array}$ \\
\hline Q54 & Other & Please list any themes you would like us to consider for future program events \\
\hline
\end{tabular}




\section{Bibliographical Information}

[1] NACIE University Presidents Commitment Letter, April 19, 2011, http://www.innovationamerica.us/images/stories/2011/NACIE_LetterUniversity_Commercialization-20110617084146-20110617215655.pdf

[2] The Innovative \& Entrepreneurial University: Higher Education, Innovation, \& Entrepreneurship in Focus, U.S. Department of Commerse, October 2013.

[3] Duval-Couetil, N., Reed-Rhodes, T., Haghighi, S., The Engineering Entrepreneurship Survey: An Assessment Instrument to Examine Engineering Student Involvement in Entrepreneurship Education, The Journal of Engineering Entrepreneurship, Volume 2, Number 2, Special Issue 2011.

[4] Duval-Couetil, N., Dyrenfurth, M.J., Teaching Students to Be Technology Innovators: Examining Approaches and Identifying Competencies, San Antonio, TX, June 10-13, ASEE 2012.

[5] Amelink, C, Seimetz, C. N., Watford, B. A., Folgar-Lopez, J. C., Measuring Innovative Thinking Skills in Innovation Challenge Activities, Indianapolis, IN, June 15-18, ASEE 2014.

[6] Terenzini, P. T., Cabrera, A. F., Colbeck, C. L., Parente, J. M., \& Bjorklund, S. A. (2001). Collaborative learning vs. lecture/discussion: Students' reported learning gains. Journal of Engineering Education, 90(1), 123-130. doi: 10.1002/j.2168-9830.2001.tb00579.x

[7] Duval-Couetil, N., Reed-Rhodes, T., Haghighi, S., Engineering Students and Entrepreneurship Education: Involvement, Attributes and Outcomes, International Journal of Engineering Education, Vol. 28, No. 2, pp. 425-435, 2012 